\title{
食糧問題の真の姿
}

\section{The growing problem}

2010 年 7 月 29 日号 Vol. $466(546-547)$

飢餓が依然として大きな問題であり続けている。しかしそれは、一般の人々が想像するような理由からではない。 Nature は食糧問題に関係するデータの傾向を分析し、その課題を検討した。

2050 年に地球人口は 90 億人を超えると推定される。

\section{(1) 食糧が不足している国々}

2009 年には、全世界で 10 億人以上が栄養不良の状 態にあった。栄養不良とは、食糧摂取量が定常的に必 要最低エネルギー量を下回る状況をいう。その原因は、 実は十分な食糧がないことではなく、貧しくて食糧が買 えないことなのだ。現に、食糧の $30 \%$ 以上が廃棄され ている。飢餓率が最も高いのはサハラ以南のアフリカ諸 国であり、それは貧困と密接に関係している。ただし、 栄養不良人口が世界で最も多いのはアジアだ。
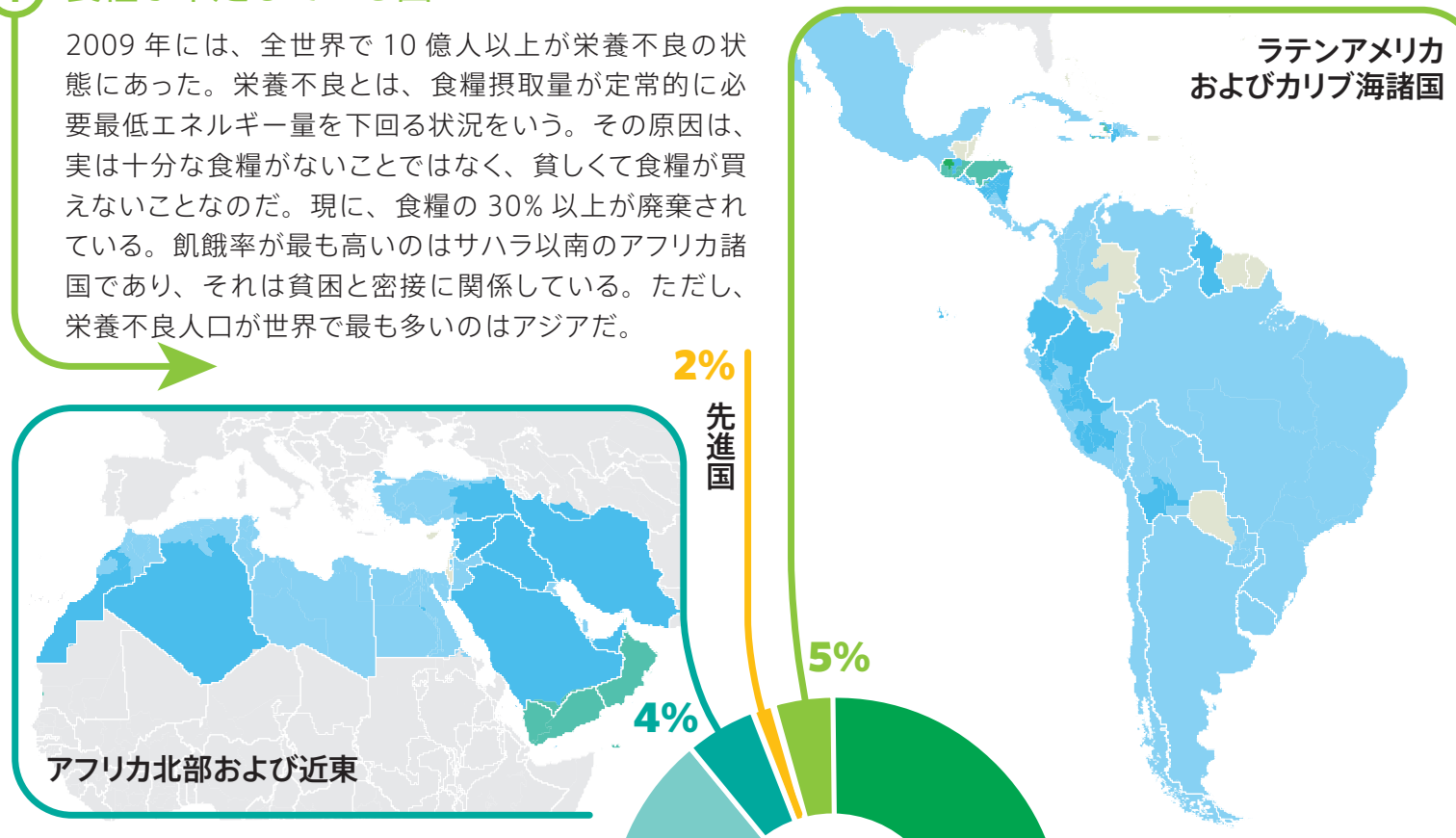

低体重の

$0 \sim 5$ 歳児の

比率

$<10.1$

$10.1-20$

20.1-30

30.1-40

$40.1-50$

$>50$

データなし

2009 年の 栄養不良人口

$26 \%$ 合計 $=10$ 億 2000 万后及

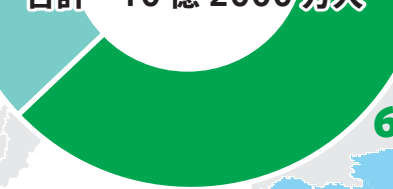
$63 \%$

極東および太平洋諸国 


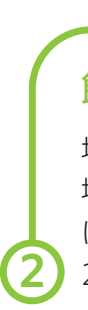

\section{飢餓は過去のものではない}

地球上の飢餓人口は、総数でいえば、一時は減少したが、現在は 増え続けている (上図)。一方、開発途上国における比率でいえ ば、飢餓人口は数十年にわたって低下傾向を示していたが (下図)、 2008 年の食糧価格危機で状況は暗転してしまった。

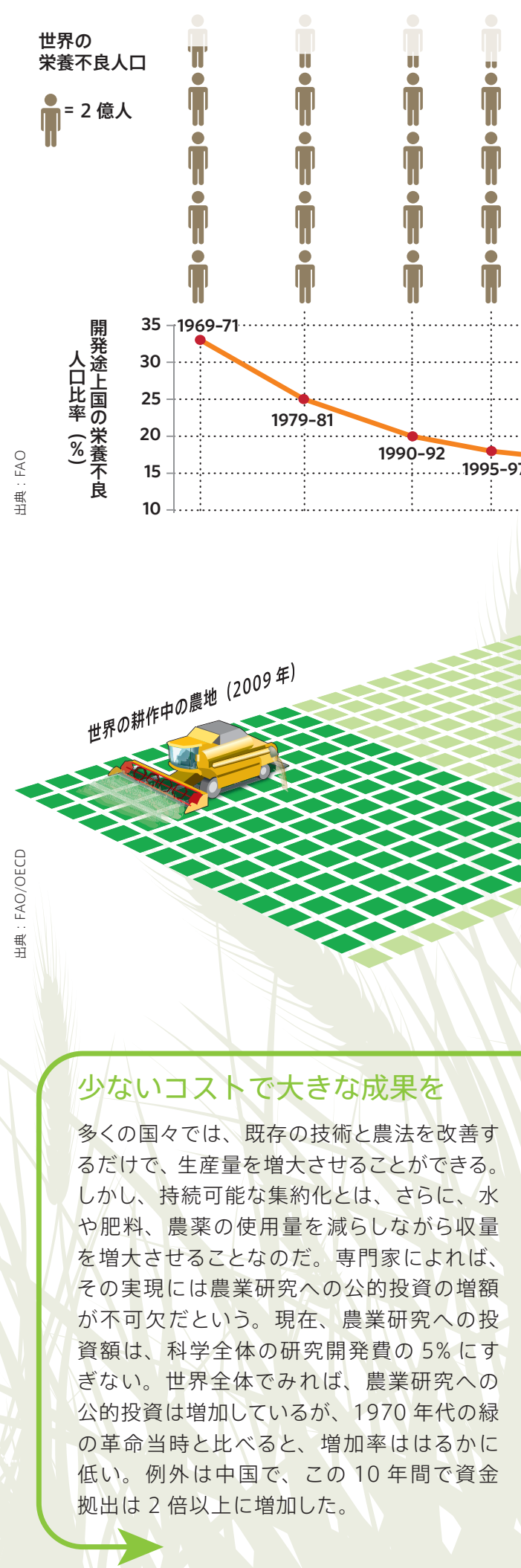

(3)

\section{人口爆発が問題なのではない}

人口の急増が食糧生産を圧迫する、という懸念が専門家の間 で長年語られてきた。しかし今や、世界人口の増加は減速して おり、2050 年には安定化するとみられる。ほぼすべての貧困 国で家族が少人数化し、子どもは 1 戸当たり約 2.2 人まで減 少するのだ。人口が増加してきたにもかかわらず、1 人当たり の入手可能な総カロリー量は、減少どころか増加している。将 来、十分な量の食糧を生産することは可能だが、水をはじめと する資源を損なうことなくそれを達成するのは難しいだろう。

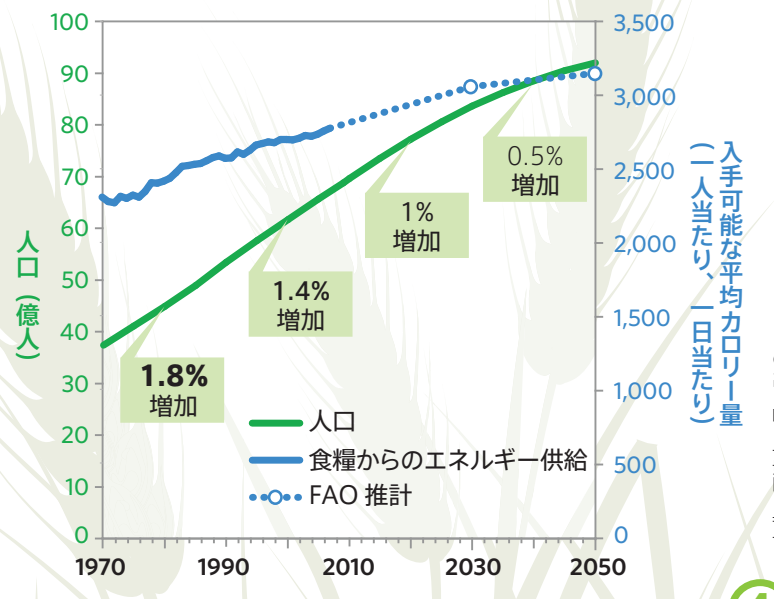

\section{農地面積も問題ではない}

国連食糧農業機関（FAO）と経済協力開発機 構 (OECD) が 2009 年に発表した見通し (go. nature.com/DdNYvk）によれば、農地面積 は、主としてラテンアメリカとアフリカの 16 億 ヘクタールを加えれば、現状の 2 倍以上に増 やすことが可能だ。それは、森林や保護区域、 都市化に必要な土地とかち合うことなく、であ る。しかし英国学士院は、耕作地の大幅な拡 大は生態系と生物多様性を損なうと警告してい る (go.nature.com/YJ2jsB)。その代わりに「持 続可能な集約化」を推奨しており、これが現在、 多くの農業研究機関の優先課題となっている。

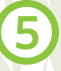

$=1000$
5

\section{研究開発費総額 (7827 億ドル = 約 67 兆円) *}

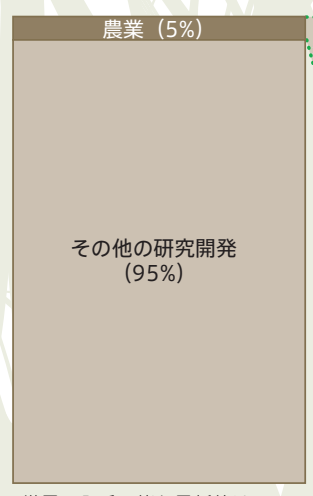

“世界の入手可能な最新值は 2000 年から 2005 年の米ドル換算購買力平価で作成。

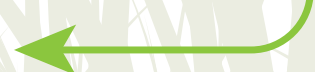

経済的分類ごとの農業研究開発費 (362 億ドル=

約 3 兆 3000 億円)

低中所得国 約 1 兆 5500 億円）の内訳

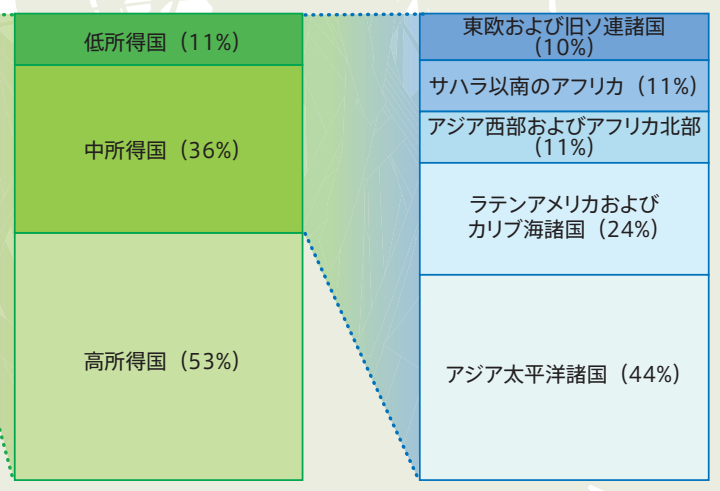

